\title{
Awareness, Practices, and Attitudes Toward the SARS-CoV-2 Outbreak Among Northern Cyprus Residents: A Descriptive Research Study Using an Online Survey
}

\author{
Kuzey Kıbrıs Türk Cumhuriyeti'nde Ikamet Edenlerin SARS-CoV-2 Salgınına Yönelik \\ Farkındalığı, Uygulamaları ve Tutumları: Çevrimiç̧i Bir Anket Kullanılarak Çalışılmıştır
}

\author{
(1) Nazife SULTANOĞLU ${ }^{1,2}$, (1) Tamer ŞANLIDAĞ² \\ ${ }^{1}$ Near East University Faculty of Medicine, Department of Medical Microbiology and Clinical Microbiology, Nicosia, Cyprus \\ ${ }^{2}$ Near East University, DESAM Research Institute, Nicosia, Cyprus
}

\section{Abstract}

Introduction: Severe acute respiratory syndrome Coronavirus-2 (SARS-CoV-2) has become a global health issue that was declared as a pandemic on March 11, 2020. The Eastern Mediterranean region, which includes the island of Cyprus, is one of the affected regions. This study aimed to analyse the awareness, practices, and attitudes towards the SARS-CoV-2 outbreak among Northern Cyprus residents during the period of a partial lockdown from April 7 to 17, 2020 through the online platform.

Materials and Methods: A descriptive research study using the online survey method was completed by Northern Cyprus residents anonymously. An online questionnaire was designed consisting of 21 questions focused on demographics (five questions), awareness (seven questions), practices (six questions), and attitudes toward the SARS-CoV-2 outbreak (three questions) and was completed by 738 Northern Cyprus residents. Statistical Package for Social Sciences Statistics, Version 24.0 was used in the statistical analysis.

Results: Facebook was the most often used platform for following news and information with regard to the SARS-CoV-2 outbreak. Additionally, most of the participants had good attitudes toward the SARS-CoV-2 outbreak, believing that Northern Cyprus would win the battle against the virus.

Conclusion: Once again, it was proven that online platforms, specifically Facebook, were the most used sources for following the news related to SARS-CoV-2. This strongly suggests that, in order to prevent dissemination of incorrect information, reliable authorities, such as the Ministry of Health, should publish information on online platforms to reach more people with correct information.

Keywords: SARS-CoV-2 outbreak, Northern Cyprus, online platform, awareness, practices

\section{Öz}

Giriş: Şiddetli akut solunum sendromu Koronavirüs-2 (SARS-CoV-2), 11 Mart 2020'de pandemi olarak ilan edilen küresel bir sağlık sorunu haline gelmiştir. Şüphesiz, Akdenizin doğusunda yer alan Kıbrıs adası da etkilenen bölgelerden biri olmuştur. Bu çalışma, 7-17 Nisan 2020 arasındaki kısmi sokağa çıkma yasağı ilan edilen dönemde Kuzey Kıbrıs Türk Cumhuriyeti'nde (KKTC) ikamet eden kişiler arasında SARS-CoV-2 salgınına yönelik farkındalığı, uygulamaları ve tutumları çevrimiçi platform aracılığıyla analiz etmeyi amaçlamıştır.

Gereç ve Yöntem: Kuzey Kıbrıs Türk Cumhuriyeti'nde ikamet edenler üzerinde çevrimiçi anket yöntemi kullanılarak tanımlayıcı bir araştırma gerçekleştirildi. Tasarlanan çevrimiçi anket, demografi (beş soru), farkındalık (yedi soru), uygulamalar (altı soru) ve SARS-CoV-2 salgınına yönelik tutumlara (üç soru) odaklanan 21 sorudan oluşuyordu. Çevrimiçi anket, KKTC'de ikamet eden 738 kişi tarafından tamamlandı. İstatistiksel analizde Statistical Package for Social Sciences 24.0 programı kullanıldı.

Bulgular: Facebook, SARS-CoV-2 salgını ile ilgili haber ve bilgileri takip etmek için en çok kullanılan platform oldu. Ek olarak, katılımcıların çoğu, KKTC'nin virüse karşı savaşı kazanacağına inanarak SARS-CoV-2 salgınına karşı iyi bir tutum içerisinde olduğunu belirttiler.

Cite this article as: Sultanoğlu N, Şanlıdağ T. Awareness, Practices, and Attitudes Toward the SARS-CoV-2 Outbreak Among Northern Cyprus Residents: A Descriptive Research Study Using an Online Survey. Mediterr J Infect Microb Antimicrob. 2021;10:11. 
Sonuç: SARS-CoV-2 ile ilgili haberleri takip etmek için en çok kullanılan platformun başta Facebook olmak üzere çevrimiçi platformlar olduğu bir kez daha kanıtlandı. SARS-CoV-2 hakkında topluma yayılabilecek yanlış bilgileri önlemek adına Sağlık Bakanlığı gibi güvenilir kaynakların daha fazla kişiye doğru bilgilerle ulaşmak için çevrimiçi platformlarda bilgi yayınlamaları gerektiğini önemle göstermektedir.

Anahtar Kelimeler: SARS-CoV-2 salgını, Kuzey Kıbrıs Türk Cumhuriyeti, çevrimiçi platform, farkındalık, uygulamalar

\section{Introduction}

The causative agent of coronavirus disease-2019 (COVID-19) is a new strain of coronavirus not previously identified in humans, which was later identified as Severe Acute Respiratory Syndrome Coronavirus-2 (now abbreviated SARS-CoV-2). SARSCoV-2 was first detected in the city of Wuhan, Hubei Province, China in December 2019 ${ }^{[1-3]}$. Shortly thereafter, SARS-CoV-2 emerged as a global pandemic, officially declared by the World Health Organization on March 11, 2020, and has since become a significant global health problem ${ }^{[4]}$.

Although the SARS-CoV-2 outbreak first emerged in China, with effective control measures, the country has successfully managed the outbreak. However, SARS-CoV-2 infections continue to arise elsewhere in the world. In the Eastern Mediterranean region, 1.903,547 cases and 50,466 deaths had been reported as of August 30, 2020 ${ }^{[5]}$. Cyprus is an island located in the Eastern Mediterranean region. The residents of the island mainly consist of Turkish Cypriots living on the Northern part of the island and Greek Cypriots living on the southern part of the island, with populations of approximately 375,000 and 875,900 , respectively ${ }^{[6,7]}$.

This study aimed to analyse the awareness, practices, and attitudes toward the SARS-CoV-2 outbreak among residents of Northern Cyprus. Up to February 6, 2021, 2722 confirmed cases and 15 COVID-19 related deaths had occurred in Northern Cyprus. Patient zero was first identified on March 9, 2020 among a German tourist group, and Northern Cyprus immediately started to take precautions against SARS-CoV-2 transmission soon after the identification of this patient. The precautions taken against the SARS-CoV-2 outbreak in Northern Cyprus from March 10 to June 1, 2020 can be summarized as follow: all forms of collective worship were banned; all workers in the public sector were placed on administrative leave, with the exception of police, fire brigade, civil aviation, finance, and health workers; all shops and entertainment centers were closed, and only pharmacies, gas stations, bakeries, and markets remained open; all schools and universities were closed; only Northern Cyprus citizens were allowed to enter the country, and these people were quarantined for 14 days in designated locations provided by the government; and a partial daytime curfew was announced on March 23, 2020, under which people were only allowed to leave home to maintain their essential needs (market and pharmacy). Full curfew from 21:00 $\mathrm{h}$ to 06:00 $\mathrm{h}$ was also imposed to ensure that people were staying in their homes. These precautions were taken as soon as patient zero was identified ${ }^{[8-11]}$.

On June 1, 2020, some of the precautions started to be relaxed, such as the re-opening of entertainment locales; schools; and air, land, and sea borders to the country, and normalization of life in Northern Cyprus began. A total of 108 cases were reported in the days between March 9 and June 30 and from April 17, 2020 to June 30, 2020 no SARS-COV-2 cases was reported in Northern Cyprus, meaning that the strict measures taken had worked successfully to prevent the spread of the disease.

However, with the opening of land, air, and sea borders to Northern Cyprus, from July 1 to September 11, 2020, the number of newly-diagnosed SARS-CoV-2 cases started to rise, reaching a total of 541 cases. This indicates that public awareness regarding good hygiene practices has undoubtedly played a significant role in preventing further transmission of SARS-CoV-2 in Northern Cyprus, and the recent increase was due to imported cases. All the precautions taken against the SARS-CoV-2 outbreak and the COVID-19 situation in the country, such as how many tests have been performed and how many COVID-19 cases or deaths have occurred each day are announced on the official website and Facebook site of the Northern Cyprus Ministry of Health ${ }^{[12,13]}$.

\section{Materials and Methods}

\section{Study Design}

This was a descriptive research study using the online survey method implemented in the period of partial lockdown from April 7 to 17, 2020 on Northern Cyprus residents. An online questionnaire was designed and consisted of 21 questions: five were about demographics, seven were related to awareness, six refered to practices implemented against SARS-CoV-2, and three were about attitudes toward the SARS-CoV-2 outbreak among Northern Cyprus residents. The survey questions were prepared in Turkish, as this is the mother tongue of Turkish Cypriots living in Cyprus. There were some limitations to this study, for example, the survey could only be filled out by participants who had internet access and technological devices 
such as a smartphone or computer. Also, the form was in Turkish; thus, only people who could read and write Turkish were able to participate. Results were obtained via the internet, which was a major source of selection bias. No consent form was required because the study did not include any clinical trials. The results of the study were obtained via an online survey, which was based on the principle of voluntary participation.

\section{Statistical Analysis}

SPSS Statistics, Version 24.0 (Armonk, NY: IBM Corp. Released 2016) was used in the statistical analysis of the research data, and frequency analysis was performed to identify the participants' socio-demographic characteristics as well as their awareness, practices, and attitudes toward the COVID-19 pandemic. The Pearson chi-square test and Fisher's exact test were both performed to compare participants' attitudes toward SARSCoV-2 according to their socio-demographic characteristics. Differences were considered significant at $p<0.05$. The study was approved by the Near East University Ethical Committee (YDU/2020/78-1041).

\section{Results}

\section{Socio-demographic Characteristics}

A total of 738 participants completed the survey, of which $497(67.3 \%)$ were female and 241 (32.7\%) were male. All the participants were assumed to be Northern Cyprus residents, since it was clearly mentioned in the beginning of the survey that "only Northern Cyprus residents should complete the survey". Six hundred sixty-four (90\%) of the participant stated that they were Northern Cyprus citizens, whereas $74(10 \%)$ of participants were not Northern Cyprus citizen but residents of the Northern Cyprus. Among the participating individuals, 26.2\% were aged 30 or below, $30.6 \%$ were in the 31-40 -year age group, 19.2\% were $41-50,16.1 \%$ were $51-60$, and $7.9 \%$ were aged 61 or above. Furthermore, $25.5 \%$ had a high school education, 38.8\% were undergraduates, $19.1 \%$ were postgraduates, and $10.2 \%$ had a $\mathrm{PhD}$. Fifty-four percent resided in Nicosia, 14.0\% in Famagusta, and $23.0 \%$ in Kyrenia. The participants were distributed by occupation as follows: $14.0 \%$ freelance worker, $10.4 \%$ teacher, $9.1 \%$ housewife, $8.9 \%$ retired, $8.8 \%$ government official, $8.3 \%$ academician/research assistant, $6.6 \%$ health worker, and 33.9\% stated other occupations on various subjects.

\section{Awareness of Participants Toward COVID-19}

Participants' awareness of COVID-19 is reported in Table 1. When asked where they first heard about the SARS-CoV-2 pandemic in Northern Cyprus, 76.9\% of participants responded "via social networks", and 20.2\% "via radio/TV/newspaper". Among the participants, $87.0 \%$ followed news, developments, and measures about the COVID-19 pandemic on Facebook, 66.3\% on television, 23.4\% on SMS messages sent by the government, and $11.4 \%$ on Twitter. With regard to social media, $69.1 \%$ of participants followed the accounts of the Northern Cyprus Ministry of Health (Facebook, Instagram), 48.1\% followed those of local newspapers (Facebook, Instagram), 36.3\% followed those of the Northern Cyprus Prime Ministry's Office Directorate of Crisis Communication, and 15.0\% followed anonymous social media (Facebook, Instagram etc.) group(s) and other similar pages. Among the participants, $80.0 \%$ reported hearing that "all shops, establishments, casinos, night clubs, betting offices, entertainment centers etc. would be closed other than services that provide for basic needs in the private sector, such as pharmacies, petrol stations, and supermarkets", 78.3\% heard that there would be a "14-day quarantine for Northern Cyprus citizens if they come from abroad", $71.0 \%$ heard that "there will be administrative leave for all public officers other than police, fire department, health, civil aviation, financial matters etc.," $56.8 \%$ heard that there would be "no access between districts in Northern Cyprus", and 60.6\% said they heard that there would be "no gatherings at associations, clubhouses, or places of public worship". Furthermore, 96.3\% of participants indicated that the most common symptoms of COVID-19 are fever, while $87.1 \%$ said dyspnea, and $86.2 \%$ said dry cough. In terms of COVID-19 transmission, $96.2 \%$ of participants indicated that SARS-CoV-2 is transmitted via the sneeze and/or cough of a COVID-19 infected person, 94.9\% said from close contact with an infected person, and $94.0 \%$ said via touching the mouth, nose, or eyes after contact with infected objects. In all, $96.8 \%$ of participants noted that COVID-19 "severely affects the elderly and people with weak immune systems and chronic diseases", 92.6\% stated that "its incubation period is between 2 and 14 days", $41.5 \%$ said that the agent of "COVID-19 is called SARS-CoV-2", and $25.6 \%$ indicated that it has a "low mortality rate".

\section{Practices During the COVID-19 Pandemic Among Residents of} Northern Cyprus

The general practices related to SARS-CoV-2 adopted by the participants are reported in Table 2. According to the survey, $96.9 \%$ of participants wash their hands with water and soap for at least 20 seconds to prevent the spread of the COVID-19; 93.8\% avoid hugging, hand-shaking, and kissing; 91.1\% use antiseptic hand gel or cologne when they have no access to soap and water; and $88.1 \%$ use disposable tissues when coughing and sneezing or they sneeze and cough into their elbow if there is no paper tissue. In terms of when participants wash their hands; 85.5\% wash their hands after using the toilet, 92.7\% wash them before preparing food, $91.2 \%$ wash them before eating, $87.4 \%$ wash them after wiping their nose, coughing, or sneezing, and $58.8 \%$ wash them after contact with animal feed or animals. Among the participants, 93.0\% said they often let fresh air in through windows for house and surface cleanliness, 
Table 1. Participants' awareness of Coronavirus disease-2019

\begin{tabular}{|c|c|c|}
\hline Where they first heard about COVID-19 & $\mathbf{n}$ & $\%$ \\
\hline Social Networks & 567 & 76.8 \\
\hline Radio/TV/Newspaper & 149 & 20.2 \\
\hline Friends/Relatives & 22 & 3.0 \\
\hline \multicolumn{3}{|l|}{ Where to follow information, developments, and measures about the COVID-19 outbreak } \\
\hline Facebook & 642 & 87.0 \\
\hline TV channels & 489 & 66.3 \\
\hline SMS by Northern Cyprus government & 170 & 23.0 \\
\hline Newspapers & 159 & 21.5 \\
\hline Twitter & 84 & 11.4 \\
\hline YouTube & 62 & 8.4 \\
\hline Official authorities & 30 & 4.1 \\
\hline Radio & 67 & 9.1 \\
\hline \multicolumn{3}{|l|}{ Social networks for COVID-19 developments } \\
\hline Social media pages of the Northern Cyprus Ministry of Health (Facebook, Instagram) & 510 & 69.1 \\
\hline Local news page(s) on social media (Facebook, Instagram) & 355 & 48.1 \\
\hline Social media page of Northern Cyprus Prime Ministry Directorate of crisis communication & 268 & 36.3 \\
\hline Anonymous social media (i.e., Facebook, Instagram) group(s) etc. & 111 & 15.0 \\
\hline None & 28 & 3.8 \\
\hline \multicolumn{3}{|l|}{ Previous Information on the measures and precautions taken in Northern Cyprus for the COVID-19 pandemic } \\
\hline $\begin{array}{l}\text { All shops, establishments, casinos, night clubs, bet offices, entertainment centers etc. will be closed other than services that } \\
\text { provide basic needs in the private sector like pharmacies, petrol stations, and supermarkets }\end{array}$ & 590 & 80.0 \\
\hline 14-day quarantine for Northern Cyprus citizens if they come from abroad & 578 & 78.3 \\
\hline Administrative leave for all public officers other than police, fire department, health, civil aviation, financial matters etc. & 524 & 71.0 \\
\hline No access between districts in Northern Cyprus & 419 & 56.8 \\
\hline No gatherings at associations and clubhouses, or public worship & 447 & 60.6 \\
\hline None & 12 & 1.63 \\
\hline \multicolumn{3}{|l|}{ Most common symptoms of COVID-19 } \\
\hline High fever & 711 & 96.3 \\
\hline Dyspnea & 643 & 87.1 \\
\hline Dry cough & 636 & 86.2 \\
\hline \multicolumn{3}{|l|}{ Mode of SARS-CoV-2 transmission } \\
\hline Sneeze and/or cough from a COVID-19 infected person & 710 & 96.2 \\
\hline Close contact with an infected person & 700 & 94.9 \\
\hline Touching the mouth, nose or eyes after contact with infected objects & 693 & 93.9 \\
\hline No idea & 3 & 0.4 \\
\hline \multicolumn{3}{|l|}{ COVID-19 characteristics } \\
\hline Severe effect on elderly, people with weak immune systems and chronic diseases & 714 & 96.8 \\
\hline Incubation period between 2-14 days & 683 & 92.6 \\
\hline COVID-19 agent is called SARS-CoV-2 & 306 & 41.5 \\
\hline Low mortality rate & 189 & 25.6 \\
\hline
\end{tabular}


Table 2. Participants' practices regarding Coronavirus disease-2019

\begin{tabular}{l|l|l}
\hline Hygiene rules during the CoVID-19 pandemic & $\mathbf{n}$ & \multicolumn{1}{l}{$\%$} \\
\hline $\begin{array}{l}\text { I frequently wash my hands with water and soap for } \\
\text { at least 20 seconds }\end{array}$ & 715 & 96.9 \\
\hline I avoid hugging, hand-shaking, and kissing & 692 & 93.8 \\
\hline $\begin{array}{l}\text { When water and soap are not available, I use } \\
\text { antiseptic hand gel or cologne }\end{array}$ & 672 & 91.1 \\
\hline $\begin{array}{l}\text { I use disposable tissues when coughing and sneezing } \\
\text { or I sneeze and cough into my elbow if there is no } \\
\text { paper tissue }\end{array}$ & 650 & 88.1 \\
\hline When to wash hands with water and soap & & \\
\hline After using the toilet & 705 & 95.5 \\
\hline Before preparing food & 684 & 92.7 \\
\hline Before eating & 673 & 91.2 \\
\hline After wiping my nose, coughing or sneezing & 645 & 87.4 \\
\hline After contact with animal feed or animals & 434 & 58.8 \\
\hline Sometimes wash my hands for less than 20 seconds & 205 & 27.8 \\
\hline
\end{tabular}

Issues related to in house and surface cleanliness during the COVID-19 pandemic

\begin{tabular}{l|l|l}
\hline I often let fresh air in from windows & 686 & 93.0 \\
\hline $\begin{array}{l}\text { I clean the most touched surfaces (door knob, sockets } \\
\text { etc.) with bleach or alcohol-based cleaning agents }\end{array}$ & 621 & 84.2 \\
\hline $\begin{array}{l}\text { I clean cell phones, tablets, and computer keyboards } \\
\text { with alcohol-based disinfectants or cologne }\end{array}$ & 578 & 78.3 \\
\hline No cleaning & 9 & 1.2 \\
\hline
\end{tabular}

Following the curfew rules in Northern Cyprus

\begin{tabular}{|c|c|c|}
\hline I go to the supermarket and pharmacy & 582 & 78.9 \\
\hline I go to the bank & 103 & 14.0 \\
\hline I do not leave the house & 150 & 20.3 \\
\hline I go to the park & 3 & 0.4 \\
\hline \multicolumn{3}{|l|}{ Precautions taken when outdoors } \\
\hline I wear a mask even without symptoms & 556 & 75.3 \\
\hline I do not touch my mouth, nose or eyes & 627 & 85.0 \\
\hline I keep at least one-meter social distance & 697 & 94.4 \\
\hline I wear gloves & 535 & 72.5 \\
\hline I wear a mask if I have symptoms (i.e., cough, sneeze) & 81 & 11.0 \\
\hline I do not take any precautions & 2 & 0.3 \\
\hline
\end{tabular}

Precautions when returning home from outside during the COVID-19 pandemic

\begin{tabular}{l|l|l}
\hline I do not enter the house with my shoes & 631 & 85.5 \\
\hline $\begin{array}{l}\text { I immediately wash my hands with water and soap } \\
\text { for at least } 20 \text { seconds }\end{array}$ & 699 & 94.7 \\
\hline I wash my clothes & 540 & 73.2 \\
\hline I take a shower & 462 & 62.6 \\
\hline I enter the house after disinfecting my shoes & 141 & 19.1 \\
\hline COVID-19: Coronavirus disease-2019 &
\end{tabular}

84.4\% said they clean most touched surfaces (door knobs, light switches, etc.) with bleach or alcohol-based cleaning agents, and $78.3 \%$ clean cell phones, tablets, and computer keyboards with alcohol-based disinfectants or cologne.

With regard to meeting their needs, $78.9 \%$ said they go to the supermarket and pharmacy, $14.0 \%$ go to the bank, and $20.3 \%$ do not leave the house. Survey participants revealed that once outdoors the following precautions were taken; With respect to wearing masks, it was found that $75.3 \%$ of participants wear a mask even without symptoms, $85.0 \%$ do not touch their mouth, nose, or eyes, 94.5\% keep at least a 1-m social distance, and $72.5 \%$ wear gloves. With regard to the precautions taken during the COVID-19 pandemic when they return home after being outside, $85.5 \%$ do not enter the house with shoes, $94.7 \%$ immediately wash their hands with soap and water for at least 20 seconds, 73.2\% wash their clothes, $62.6 \%$ take a shower, and $19.1 \%$ enter the house only after disinfecting their shoes.

\section{Attitudes of Participants Toward the COVID-19 Pandemic}

A majority of the participants agreed that increasing awareness of the SARS-CoV-2 in Northern Cyprus is important to prevent the spread of the disease (96.9\%), and $83.2 \%$ believed that Northern Cyprus would win the fight against SARS-CoV-2, whereas only $41.3 \%$ participant stated that the measures taken against the SARS-CoV-2 outbreak in Northern Cyprus were sufficient (Table 3).

Moreover, Table 4 presents the chi-square test results for the participants and their socio-demographic characteristics regarding whether they find the COVID-19 measures sufficient. There was a statistically significant difference between age groups regarding their opinions on the sufficiency of the current COVID-19 measures. A higher proportion of participants in the 41-50 and 51-60 age groups found the current COVID-19 measures sufficient, when compared with all other age groups

\section{Table 3. Participants' attitudes toward Coronavirus} disease-2019

\begin{tabular}{l|l|l}
\hline $\begin{array}{l}\text { Sufficiency of the measures taken against } \\
\text { COVID-19 }\end{array}$ & $\mathbf{n}$ & $\mathbf{\%}$ \\
\hline Sufficient & 305 & 41.3 \\
\hline Not sufficient & 433 & 58.7 \\
\hline
\end{tabular}

Is the awareness of COVID-19 in Northern Cyprus important in preventing the spread of disease?

\begin{tabular}{l|l|l}
\hline Yes & 715 & 96.9 \\
\hline No & 23 & 3.1 \\
\hline
\end{tabular}

Do you believe that Northern Cyprus will win the fight against the COVID-19?

\begin{tabular}{l|l|l}
\hline Yes & 614 & 83.2 \\
\hline No & 124 & 16.8 \\
\hline COVID-19: Coronavirus disease-2019
\end{tabular}


$(p=0.030)$. Similarly, there was a statistically significant difference according to gender, as a lower proportion of females than males were of the opinion that COVID-19 measures are sufficient $(p=0.033)$. On the other hand, there was no statistically significant difference with regard to the participants' educational status and their opinions on whether or not the current COVID-19 measures are sufficient $(p=0.156)$. There was a statistically significant difference between citizens of Northern Cyprus and participants of other nationalities, as $60.4 \%$ of Northern Cyprus citizens stated that the imposed measures against SARS-CoV-2 (COVID-19) are not sufficient $(p=0.04)$.

\section{Discussion}

The present study aimed to demonstrate the awareness, practices, and attitudes toward the SARS-CoV-2 outbreak in Northern Cyprus. Many studies have examined the various levels of knowledge, attitudes, and practices toward SARSCoV-2 in different countries, including Saudi Arabia and China ${ }^{[12]}$. However, no studies or public reports have been found regarding SARS-CoV-2 among the residents of Northern Cyprus. The research conducted here revealed that awareness and practices toward SARS-CoV-2 among the Northern Cyprus population are generally good. In terms of following the information, developments, and measures about COVID-19 in Northern Cyprus, Facebook was the most cited medium, followed by television channels, with rates of $87.0 \%$ and $66.3 \%$, respectively.

The social media pages of the Northern Cyprus Ministry of Health were the most used network sources among other social media pages, and $69.1 \%$ of respondents reported using this channel, suggesting a key role for announcements by the ministry during the outbreak. Also, people were aware of the symptoms and modes of transmission of COVID-19. Apart from their level of awareness, Northern Cyprus residents were also following the suggested practices during the SARS-CoV-2 outbreak; for example, 96.9\% of participants said they washed their hands with soap and water for at least 20 seconds. In addition, 93.8\% said they avoided hugging and shaking hands, while $91.1 \%$ said they used hand antiseptics when soap and water were not available.

On the other hand, $41.3 \%$ of participants found the measures taken in Northern Cyprus during the SARS-CoV-2 outbreak to be insufficient. However, 83.2\% believed that Northern Cyprus will win the battle against the SARS-CoV-2 outbreak.

The survey questions were in Turkish. Thus, only people who could read and write Turkish were able to participate. The designed

Table 4. Comparison of participants regarding whether they found the Coronavirus disease-2019 measures sufficient according to their socio-demographic characteristics

\begin{tabular}{|c|c|c|c|c|c|c|}
\hline \multirow[b]{2}{*}{ Age } & \multicolumn{2}{|c|}{ Sufficient $(n=305,41.3 \%)$} & \multicolumn{2}{|c|}{ Not sufficient $(n=433,58.7 \%)$} & \multirow{2}{*}{$\chi^{2}$} & \multirow{2}{*}{$\mathbf{p}$} \\
\hline & $\mathbf{n}$ & $\%$ & $\mathbf{n}$ & $\%$ & & \\
\hline 30 and below & 69 & 35.8 & 124 & 64.3 & \multirow{3}{*}{10.679} & \multirow{3}{*}{$0.030^{*}$} \\
\hline $41-50$ age & 67 & 47.2 & 75 & 52.8 & & \\
\hline $51-60$ age & 61 & 51.3 & 58 & 48.7 & & \\
\hline \multicolumn{7}{|l|}{ Gender } \\
\hline Female & 192 & 38.6 & 305 & 61.4 & \multirow{2}{*}{4.562} & \multirow{2}{*}{$0.033^{*}$} \\
\hline Male & 113 & 46.9 & 128 & 53.1 & & \\
\hline \multicolumn{7}{|l|}{ Educational status } \\
\hline Postgraduate & 50 & 35.5 & 91 & 64.5 & \multirow{2}{*}{6.648} & \multirow{2}{*}{0.156} \\
\hline $\mathrm{PhD}$ & 36 & 48.0 & 39 & 52.0 & & \\
\hline \multicolumn{7}{|l|}{ Nationality } \\
\hline Northern Cyprus & 263 & 39.6 & 401 & 60.4 & \multirow{2}{*}{8.074} & \multirow{2}{*}{$0.004^{*}$} \\
\hline Other & 42 & 56.8 & 32 & 43.2 & & \\
\hline
\end{tabular}


survey could only be completed by participants who had internet access and technological devices such as smartphones or computers. Results were obtained via the internet, which was a major source of selection bias.

\section{Conclusion}

In summary, our findings indicate that Northern Cyprus residents have good knowledge and practices, as well as optimistic attitudes toward the SARS-CoV-2 outbreak. Without a doubt, citizens' knowledge and practices applied during the outbreak is critical in the prevention of the spread of the disease.

\section{Acknowledgments}

I would like to thank my fiancé Cemal Yazır and my sister Fatma Sultanoğlu for helping me to distribute the online survey and supporting me with the statistical analysis.

\section{Ethics}

Ethics Committee Approval: The study was approved by the Near East University Ethical Committee (YDU/2020/78-1041).

Informed Consent: No consent form was required because the study did not include any clinical trials.

Peer-review: Externally and internally peer-reviewed.

\section{Authorship Contributions}

Design: N.S., T.Ş., Data Collection or Processing: N.S., Analysis or Interpretation: N.S., T.Ş., Literature Search: N.S., T.Ş., Writing: N.S.

Conflict of Interest: No conflict of interest was declared by the authors.

Financial Disclosure: The authors declared that this study received no financial support.

\section{References}

1. Bhagavathula SA, Aldhaleei WA, Rahmani J, Mahabadi MA, Bandari DA Novel Coronavirus (COVID-19) Knowledge and Perceptions: A Survey of Healthcare Workers," medRxiv, p. 2020.03.09.20033381.

2. European Centre for Disease Prevention and Control (ECDC). "O \& $A$ on COVID-19," 2020. [Online]. Last accessed date: 03-Jul-2020. Available from: https://www.ecdc.europa.eu/en/covid-19/questions-answers

3. Kharma MY, Alalwani MS, Amer MF, Tarakji B, Aws G. Assessment of the awareness level of dental students toward Middle East Respiratory Syndrome-coronavirus. J Int Soc Prev Community Dent. 2015;5:163-9.

4. World Health Organization (WHO). "WHO Director - General's opening remarks at the media briefing on COVID-19 - 11 March 2020. Available from: https://www.who.int/director-general/speeches/detail/who-directorgeneral-s-opening-remarks-at-the-media-briefing-on-covid-19---11march-2020

5. World Health Organization (WHO). "Coronavirus disease (COVID-19) Weekly Epidemiological Update Global epidemiological situation," 2020. Available from: https://www.who.int/publications

6. TRNC State Planning Organization, "TRNC State planning Organization Main site," 2020. Available from: https://www.devplan.org/index_en.html

7. Republic of Cyprus Ministry of Finance, "Demographic Statistics," 2018. p. 1-12. Available from: https://www.mof.gov.cy/mof/cystat/statistics. nsf/All/0F27BA4B99ABE197C22584BA003C9DED/\$file/Demographic_ Statistics-2018-EN-291119.pdf?0penElement

8. Yeniduzen, "Schools are in holiday until Monday, March 16," 2020. [Online] Available from: https://www.yeniduzen.com/okullar-16-mart-pazartesinekadar-tatil-124707h.htm

9. detaykibris, "Here are the decisions taken by the Council of Ministers, administrative leave until 27 March in the public and private sector," 2020. [Online]. Available from: http://www.detaykibris.com/corona-istebakanlar-kurulunun-aldigi-kararlar-kamuda-27-marta-kadar-izin-ozeldeisy-211733h.htm

10. kibrisadahaber, "Partial curfew continues in Turkish Republic of Northern Cyprus (TRNC)," 2020. [Online]. 03-Jul-2020] Available from: https://www. kibrisadahaber.com/kktcde-kismi-sokaga-cikma-yasagi-suruyor-234191h. htm

11. Sultanoglu N, Baddal B, Suer K, Sanlidag T. Current situation of COVID-19 in northern Cyprus. East Mediterr Health J. 2020;26:641-5.

12. TRNC Ministry of Health, "TRNC Ministry of Health - Main site," TRNC Ministry of Health, 2020. Available from: https://saglik.gov.ct.tr/

13. KKTC Sağlık Bakanlığı Facebook, "KKTC Sağlık Bakanlığı Facebook," 2012. Available from: https://www.facebook.com/kktcsaglikbakanligi/ 